\title{
An evaluation of the compression strength of gypsum according to proportion and manipulation
}

\author{
Resistência à compressão de gessos em função do proporcionamento e manipulação \\ Paulo Eduardo Capel CARDOSO \\ Doctor Professor - Dental Materials Department - Dental School of São Paulo - USP - São Paulo - SP - Brazil \\ Paulo Afonso BURMANN \\ Doctor Professor - Chairmen's Prosthesis Departmnent - UFSM - Santa Maria - RS - Brazil
}

Luciano ANZILIERO

Dental Practioner - Prothesis Especialisty -

Jomara Marchi Ferreira Santos CARDOSO

Colaboradora do Núcleo de Apoio à Pesquisa em Materiais Dentários (NAPEM) - da Faculdade de Odontologia da Universidade de São Paulo - USP - São Paulo - SP - Brazil

\section{Andréa Urbano TAVARES}

Fernanda Tranchesi SADEK

Post-graduated student - Dental Materials Program - Dental School of São Paulo - USP - São Paulo - SP - Brazil

\begin{abstract}
This study evaluated the compression strength of gypsum type IV and V according to 2 variables: 1) water proportioned randomly or as recommended by the manufacturer and 2) according to 3 (three) different groups of operators (dentists, technicians and dental students). 180 specimens, produced according to ADA regulation nr. 25 underwent, after seven days (dry resistance), the compression strength test in an universal testing machine. After statistical analyses of the data, there was no statistical significant difference regarding the group of operators. Regarding the variable proportion, the specimens manufactured using a random proportion of water/gypsum powder presented a lower compression value $\left(626,2 \mathrm{Kgf} / \mathrm{cm}^{2}\right)$ when compared to the group where the amount of water/gypsum powder followed the recommendation of the manufacturer $\left(741,7 \mathrm{Kgf} / \mathrm{cm}^{2}\right)$. This difference was statistically significant $(\mathrm{p}<0.01)$.
\end{abstract}

\section{UNITERMS}

Calcium sulfate; dental impression materials; alginates; dental models

\section{INTRODUCTION}

The use of gypsum in dentistry is wide, ranging from the manufacture of models, dies, mounting for dental articulators, filling for denture flasks, binder for investments $2,8,12,18$. Because of the considerable use of gypsum, it is a must that this material has an adequate mechanical resistance and reproduces precisely the original model ${ }^{4-7,9,12,15}$. These properties are dependent upon a number of factors, such as: the correct water/gypsum powder ratio, mixing energy and storage conditions ${ }^{2,12}$.
Nevertheless, every day use has led to a careless proportion and manipulation of certain materials, such as alginates, gypsums and investiments ${ }^{14,17}$. This may lead to changes in the physical properties of models and patterns, such as low superficial hardness, low mechanical resistance and dimensional change ${ }^{2,5,12,15}$. Regarding gypsum, the inadequate water/powder ratio (randomly), in the expectation of saving clinical time, can lead to countless alterations which can jeopardize the quality of the prosthetics work.

According to Anusavice ${ }^{2}$ (1998), the higher the water/powder ratio, the longer will be the setting time 
and the weaker will be the final product. The resistance is related to the greater porosity of the final product, as there is more water in the mixture. Still, during mixing of the powder and water, if their proportion is arbitrarily measured, the addition of more powder to a mixture that was excessively fluid will result in two different mixtures of gypsum, with different setting times, generating a final product that is much less resistant mechanically. In the same manner, the addition of more water to a mixture that was too stilted may lead to a disorganization of the crystal growth and reduction on the cohesion among the crystals.

The resistance properties are inversely proportional to the water/powder ratio. Therefore, for a gypsum based product, if a maximum resistance is desired, this material should be obtained with the smaller water/powder ratio possible, within the limits recommended by the manufacturer ${ }^{10,13}$. It should also be noted that a lower water/powder ratio will lead to a setting expansion ${ }^{2,12}$.

Another factor that may alter the properties of gypsum is related to the techniques of blending, which can be manual or mechanical, with or without vacuum. Also, there is the speed and the pressure of the spatula on the mixture. On the manual blending there is a direct correlation with the physical characteristics of the operator, which can influence the final quality of the gypsum ${ }^{2,12}$.
There are many different mechanical tests which can be used to evaluate the properties of the gypsum, such as: superficial hardness, expansion, resistance of abrasion and compressive strength ${ }^{3,5,11,19}$. According to O'Brien ${ }^{12}$ (1981), the compressive strength of gypsums is a good indicative to evaluate the superficial hardness and resistance of abrasion. It is also related with a correct water/powder ratio and manipulation.

Even though it may seem obvious that an alteration in the water/powder ratio for gypsum products will lead to problems in the final product, the literature does not show studies that evaluated how the random water/powder ratio, or even the operator, can influence on the resistance of gypsum products.

The aim of this study was to evaluate if there is an influence of the water/powder ratio and of the operator on the compressive strength of gypsum type IV and V.

\section{Materials And Method}

The compressive strength tests were made using gypsum type IV (Denstply) and type V (Polidental), having as variables the water/powder ratio (as recommended by the manufacturer or casually) and the operators. The variable "operator" was divided into 3 groups, as described:

Picture 1 - Number of specimens per variables

\begin{tabular}{|c|c|c|c|c|}
\hline \multirow{2}{*}{ Operator } & \multirow{2}{*}{ Water/powder ratio $^{*}$} & \multicolumn{2}{|c|}{ Gypsum type } & \multirow{2}{*}{ Specimens } \\
\cline { 3 - 4 } & & IV & V & \multirow{2}{*}{30} \\
\hline $\mathrm{A}$ & Casual $^{*}$ & 15 & 15 & 30 \\
\hline \multirow{2}{*}{$\mathrm{P}$} & Recommended $^{*}$ & 15 & 15 & 30 \\
\cline { 2 - 4 } & Casual $^{*}$ & 15 & 15 & 30 \\
\hline \multirow{2}{*}{$\mathrm{T}$} & Recommended $^{*}$ & 15 & 15 & 30 \\
\cline { 2 - 4 } & Casual & 15 & 15 & 30 \\
\hline
\end{tabular}

\footnotetext{
* for the casual or random variable, the amount of water casually or randomly added was determine visually by the operator, to mix with 79 grams of gypsum (type IV and V)
} 
Group A: five students on the last semester of Dental School;

Group P: five dentists with at least five years of experience;

Group T: five technicians with at least five years of experience.

Each operator manufactured three specimens for each experimental condition (Picture 1). Specimens were obtained using a standard metallic cylinder, $3 \mathrm{~cm}$ high and $1.5 \mathrm{~cm}$ in diameter, according to the ADA regulation number $25^{1}$.

All specimens were made using manual blending for 45 seconds, in a bowl with a rigid spatula.

After specimens with arbitrary amount of water for the pre-dosed amount of powder were produced, new samples were made, this time with pre-dosed amount of water as well, $15 \mathrm{ml}$ of water for $79 \mathrm{~g}$ of powder, as recommended by the manufacturer.

After 60 minutes, from the time water/powder were mixed, the samples were removed from the metal cylinders and stored for seven days at room temperature and humidity. After which the samples underwent the compressive strength test, in a Riehle international testing machine, at a speed of $0.5 \mathrm{~cm} /$ $\min$.

\section{Results}

The values obtained in the compressive strength test were submitted to statistical analyses (ANOVA). Results are shown in Table 1.

Table 1 - Statistical analyses of the compressive strength for Gypsum type IV and V, according to the type (IV or V), proportion (casual or according to the recommendation of the manufacturer) and operator (dental student, dentist, and technician)

\begin{tabular}{c|c|c|c}
\hline Factor & GL & QM & RQM \\
\hline Gypsum type & 1 & 5331.299 & 0.187 n.s. \\
Proportion & 1 & 288432.276 & $10.114^{* *}$ \\
Type X Proportion & 1 & 88055.156 & 3.088 n.s. \\
Operator & 2 & 6960.601 & 0.244 n.s. \\
Type X Operator & 2 & 706.919 & 0.025 n.s. \\
Proportion X Operator & 2 & 81639.434 & 2.863 n.s. \\
Type X Proportion X Operator & 2 & 19933.447 & 0.699 n.s. \\
Residues & 168 & 28518.694 & \\
\hline Total & 179 & & \\
\hline
\end{tabular}

** Significant at 0.05

\section{Discussion}

For the results obtained in this study, except for the variable proportion, all the other factors therefore their correlations, showed no statistical significance ( $\mathrm{p}>0.05$ ).

In relation to the factor type of gypsum, the statistical analyses of the data obtained showed that the mechanical resistance of gypsum type IV and V was statistically similar, regardless of other variables.

Regarding factor proportion, it is clear that the samples made with a casual amount of water presented lower compression resistance $\left(626.2 \mathrm{Kgf} / \mathrm{cm}^{2}\right)$, when compared to the results obtained for the samples that were mixed with the recommended amount of water $\left(741.7 \mathrm{Kgf} / \mathrm{cm}^{2}\right)$ (Figure 1). 


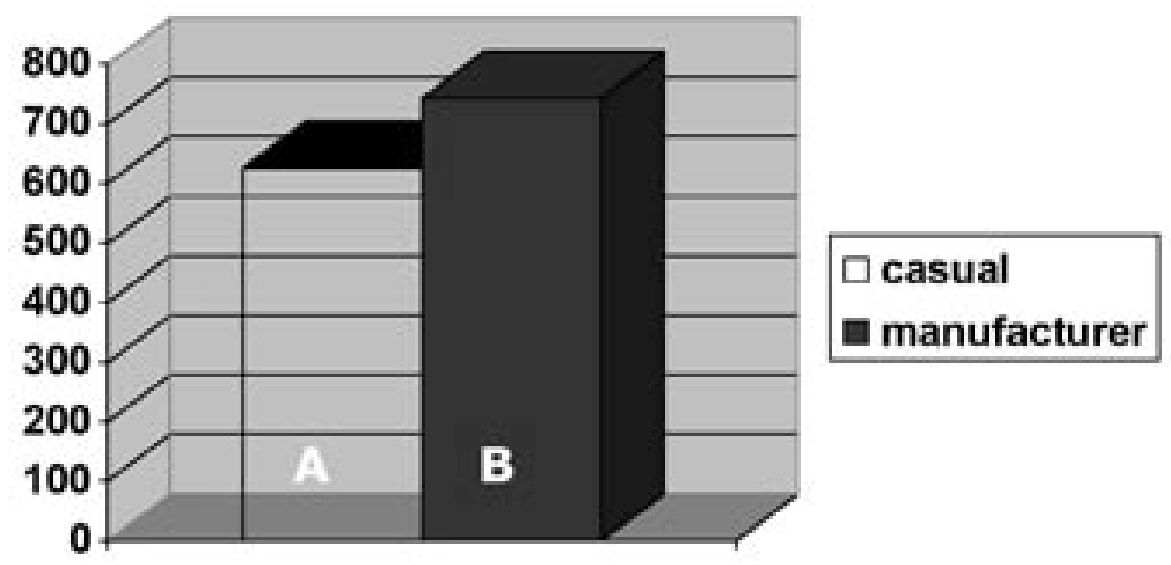

Figure 1 - Mean values of compressive strength $(\mathrm{Kgf} / \mathrm{cm} 2)$ related to proportion.

It can also be observed that the casual or random proportion of water lowered the compression results for both types of gypsum tested. Therefore it can be said that casual or random proportion of water will lead to a reduction in the compressive strength of gypsums. Thus, following the recommendation of the manufacturer is imperative in order to obtain the maximum resistance possible.

It is very interesting to note the similarity of the compression resistance values obtained by all the different operators, meaning that this variable did not influence the results $(\mathrm{p}>0.05)$. For this study, dentists, dental students and technicians made samples that ob- tained similar compressive strength. This is probably due to the fact that gypsum is a material that is easy to manipulate. Also, there was standardization on the manipulation time, of 45 seconds, for all groups.

Even thought it was not the aim of this study, it was possible to observe that manipulation time as well as technique (manual or mechanical, with or without vacuum) seems to be very important, as observed by other authors ${ }^{15,16}$, for the compressive strength. It was also observed that when a manipulation time is followed, the behavior of the two types of gypsum, regarding compressive strength, follows a tendency of uniformity, regardless of the operator (Figure 2).

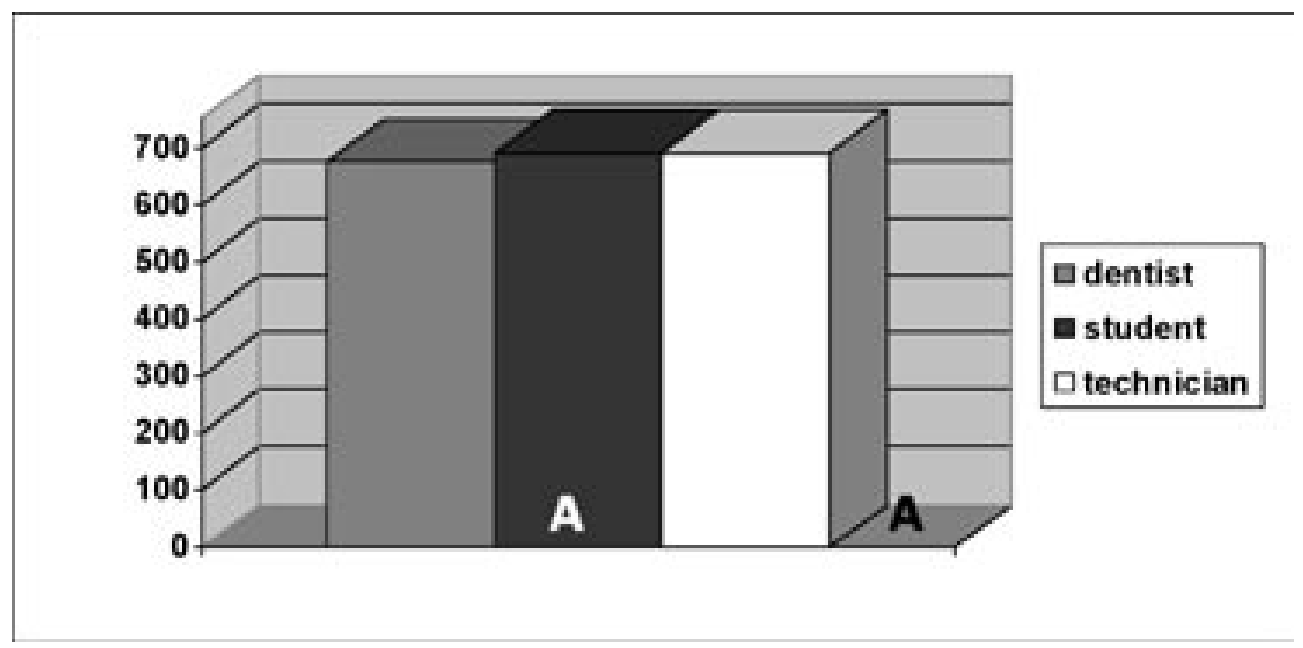

Figure 2 - Mean values of the compressive strength of gypsum $(\mathrm{Kgf} / \mathrm{cm} 2)$ related to operators 


\section{Conclusions}

1. Neither the type of gypsum nor the operators influenced the mechanical compressive strength.
2. On the other hand, causal or random proportion of water lowered the mechanical compressive strength when compared to proportion of water as recommended by the manufacturer.

\section{Resumo}

O presente estudo avaliou a resistência à compressão dos gessos tipo IV e V diante de dois tipos de proporcionamento: aleatório e recomendado pelo fabricante e três tipos de manipuladores (cirurgiões-dentistas, protéticos e estudantes de odontologia). 180 corpos de prova, padronizados conforme norma ${ }^{\circ} 25$ (ADA), foram submetidos ao teste de compressão em uma máquina de ensaio universal, após 7 dias (resistência seca). Através da análise estatística dos resultados não houve diferença significante ( $p>0.05$ ) para o fator manipulador, já para o fator proporcionamento, os corpos de prova realizados diante de uma relação água/pó aletória apresentaram menor resistência compressiva $\left(626,2 \mathrm{Kg} / \mathrm{cm}^{2}\right) \mathrm{em}$ comparação ao grupo cuja proporção seguiu a recomendação do fabricante $\left(741,7 \mathrm{Kgf} / \mathrm{cm}^{2}\right)$, sendo esta diferença estatisticamente significante em $1 \%(p<0.01)$.

\section{UNITERMOS}

Sulfato de cálcio; materiais para moldagem odontológica; alginatos;

\section{AcKNOWLedgments}

To Núcleo de Apoio à Pesquisa do Departamento de Materiais Dentários (NAPEM).

\section{References}

1. American Dental Association. Dentist's desk reference: materials, instruments and equipments. (Specification n²5) Chicago: American Dental Association; 1981.

2. Anusavice KJ. Gessos. In:__ Materiais dentários de Phillips. Rio de Janeiro: Guanabara Koogan; 1998. p.412.

3. Araújo PA, Jörgensen KD. Effect of material bulk and undercuts on the accuracy of impression materials. J Prosthet Dent. 1985 Dec.; 54(6):791-94.

4. Araújo PA, Jörgensen KD. Improved accuracy by reheating addition-reaction silicone impressions. J Prosthet Dent. 1986 Jan.; 55(1):11-12.

5. Cardoso PEC. Contribuição para o estudo das alterações dimensionais dos gessos. [dissertação] São Paulo: Faculdade de Odontologia; Universidade de São Paulo; 1991.
6. Gibson CS, Johnson RN. Investigations of setting of plaster of Paris. J Soc Chem Ind. 1932; 51(1):25-38.

7. Lima SEM, Sousa MMG, Chevitarese O. Confiabilidade de medidas em modelos de gesso. Rev Gaúcha Odontol 1995 set./out.; 43(5):263-4.

8. Mahler DB. Hardness and flow properties of gypsum products. J Prosthet Dent. 1951; 1(2):188-95.

9. Mazzeto MOE, Roselino RB, Gabrielli F, Campos GM. Estudo comparativo dos elastômeros na reprodução e transferência de detalhes para os modelos de gesso. Rev Odontol Univ São Paulo. 1990 abr./jun.; 4(2):122-9.

10. Muench A, Costa R. Resistência à compressão de gessos em função da proporção água/pó. Rev Odontol Univ São Paulo. 1978 jul./dez.; 2(16):163-8.

11. Nolasco GAB, Souza EHAG, Freitas CA. Influência do tratamento de moldes de alginato sobre a dureza de gessos odontológicos. Rev Odontol Univ São Paulo. 1991 nov./dez.; 48(6):44-7. 


\section{AN EVALUATION OF THE COMPRESSION STRENGTH OF GYPSUM ACCORDING TO PROPORTION AND MANIPULATION}

12. O’brien WL. Materiais dentários. Rio de Janeiro: Interamericana; 1981.

13. Peyton FA. Gypsum compoudns. In: Restorative dental materials. St. Louis; Mosby; 1960. p.194-230.

14. Pignataro JC. Contribuição ao uso de revestimento. [tese] Santa Maria: Faculdade de Odontologia; Universidade Federal de Santa Maria; 1965.

15. Sá DN. Técnica de medida da alteração dimensional linear de presa dos gessos odontológicos. Rev Odontol UNESP. 1992; 21(1):309-17.

16. Vieira DF, Araújo PA. Heterogeneidade na cristalização da superfície do modelo de gesso-pedra, verificado após a separação de molde e modelo. Rev Odontol Univ São Paulo. 1967 jul./set.; 5(3):231-41.

17. Vieira DF, Todescan R. Estarrecedora a situação da prótese removível. Rev Assoc Paul Cir Dent. 1972 nov./dez; 26(6):299-310.

18. Worner HK. Dental Plasters. Part I. Aust Dent J. 1942; 46(1):1-10.

19. Zani IM. Estudo comparativo de materiais para modelos analisando o comportamento dimensional e a capacidade de reprodução de detalhes em função de técnicas de vazamento. [tese] São Paulo: Faculdade de Odontologia; Universidade de São Paulo; 1994.

Recebido em:30/11/04 Aprovado em:10/05/05 